OPEN ACCESS

Edited by: Xiangzhong $\mathrm{Li}$,

Yunnan University, China

Reviewed by:

Zheng Wang,

State Key Laboratory of Loess and

Quaternary Geology, Institute of Earth

Environment (CAS), China

Xiaonan Zhang,

Yunnan University, China

Xin Zhou,

University of Science and Technology of China, China

*Correspondence:

Guoqiang Li

gqli@lzu.edu.cn

Specialty section:

This article was submitted to Quaternary Science, Geomorphology

and Paleoenvironment,

a section of the journal

Frontiers in Earth Science

Received: 24 May 2021

Accepted: 29 July 2021

Published: 14 September 2021

Citation:

Wang Z, Li G, Wang X, Gou S, Deng Y Tao S, Zhang $Y$, Yang $H$, Zhao $W$ and Jin $M$ (2021) The Elements and Color of Lacustrine Record Revealed Lake

Environmental Changes in Semiarid Northern China : A Case Study From

Chagan Nur Lake of Southern Mongolian Plateau.

Front. Earth Sci. 9:713972. doi: 10.3389/feart.2021.713972

\section{The Elements and Color of Lacustrine Record Revealed Lake Environmental Changes in Semiarid Northern China : A Case Study From Chagan Nur Lake of Southern Mongolian Plateau}

\author{
Zhong Wang ${ }^{1}$, Guoqiang $L_{i}{ }^{1 *}$, Xiaoyan Wang ${ }^{1}$, Siyi Gou ${ }^{1}$, Yanqing Deng ${ }^{1}$, Shuxian Tao ${ }^{1}$, \\ Yunian Zhang ${ }^{2}$, He Yang ${ }^{1}$, Wenwei Zhao ${ }^{3}$ and Ming Jin ${ }^{1}$ \\ ${ }^{1}$ Key Laboratory of Western China's Environmental Systems (Ministry of Education), College of Earth and Environmental \\ Sciences, Lanzhou University, Lanzhou, China, ${ }^{2}$ State Key Laboratory Breeding Base of Desertification and Aeolian Sand Disaster \\ Combating, Gansu Desert Control Research Institute, Lanzhou, China, ${ }^{3}$ School of Geographic Science, Nantong University, \\ Nantong, China
}

The lakes at the southern Mongolian Plateau are sensitive to the variation of EASM changes during the Holocene, and hence the lacustrine records of these lakes provide prospects for understanding how lake environmental changes respond to EASM variation at different timescales. The interpretation of proxy indexes of lacustrine sediments is complex due to the various climatic or/and environmental factors influencing the processes during deposition and after deposition. In this study, the elements and colors of an 11.7-m lacustrine record from Chagan Nur at the southern Mongolian Plateau of northern China were analyzed to constrain the lake environmental changes during the Holocene. The results show that stable elements of $\mathrm{Al}, \mathrm{Si}, \mathrm{K}, \mathrm{Ti}, \mathrm{Fe}$, and $\mathrm{Rb}$ are more related to surface erosion or/and vegetation coverage, and the variation of $\mathrm{Sr}$ is related to the lake-level change in Chagan Nur. The element and color of the lacustrine records show that a small and shallow lake environment occurred at Chagan Nur during 11.7-10.5 ka, the lake level had increased during 10.5-7 ka, and then the lake shrank with strength surface erosion during 7-6.2 ka and from $2 \mathrm{ka}$ to the present. The lake level and surface erosion changes of Chagan Nur have shown a direct response to EASM precipitation changes as reconstructed from the pollen record from the Chagan Nur Lake and other records from northern China.

Keywords: Northern China, elements, color, paleoenvironment, East Asia summer monsoon, Holocene

\section{INTRODUCTION}

East Asian summer monsoon (EASM) is the crucial atmospheric circulation system for East Asia, for it provided amounts of fresh water to all of the lives (An et al., 2015; Chen et al., 2015; Chen et al., 2020). The research of variations and mechanism of EASM is of significance for understanding how human beings adapt to the climatic changes in EASM dominance in the future. The southern Mongolian Plateau located at the margin of EASM is an ideal place to study the mechanism and variation of EASM. The lake sediments in these regions are the ideal carriers to reconstruct the variations of EASM intensity in the past period (Jin et al., 2006; An et al., 2012; Zhang et al., 2016; Goldsmith et al., 2017; Wen et al., 2017; Li et al., 2020; Chen et al., 2021). 


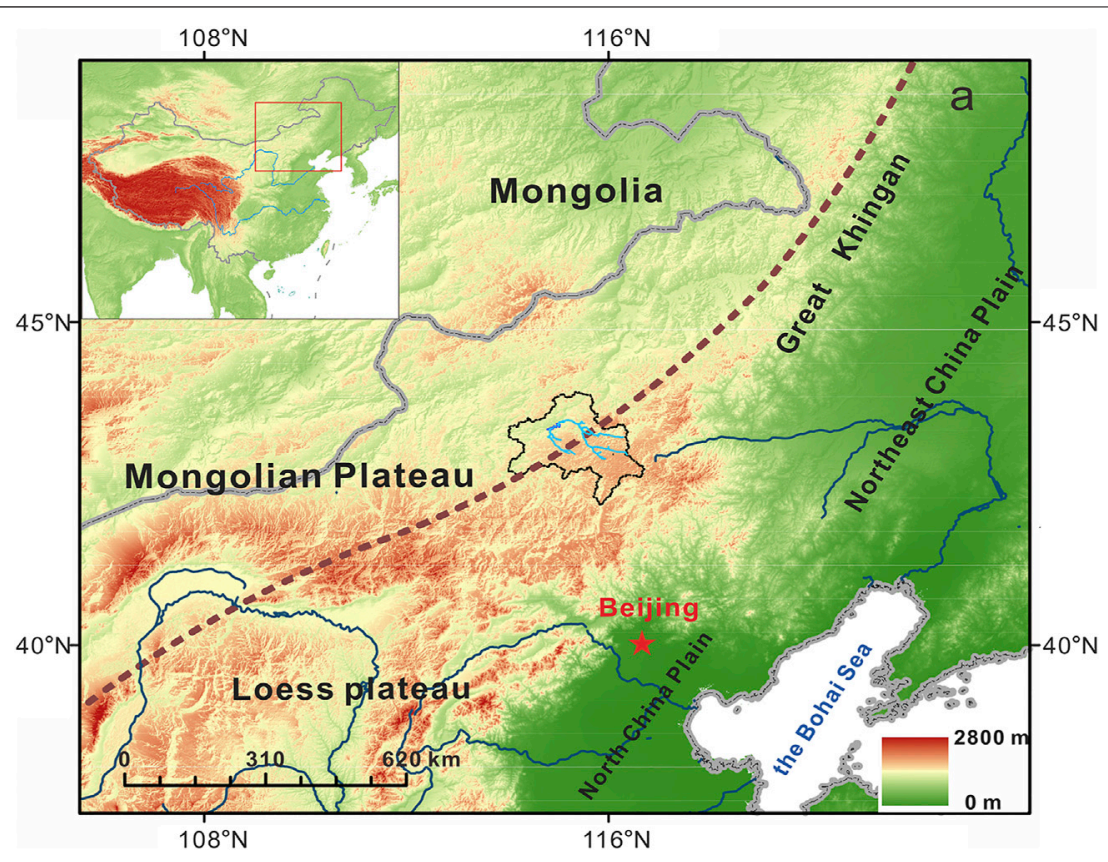

FIGURE 1 | Location of Chagan Nur basin in northern China.

Chagan Nur Lake locates at the southern Mongolian Plateau, which is exactly located at the fringe of the modern EASM. The lacustrine sediments in this lake provide reliable records for detecting the variation of EASM during the Holocene. For example, Jiang et al. (2016) and Han and Liu (2017) have reported that the paleoclimatic variations were affected by the changes of summer insolation using the proxies of grain size and pollen from west Chagan Nur over the past $2 \mathrm{ka}$ and $7 \mathrm{ka}$, respectively. Liu and $\mathrm{Ha}$ (2015) has reconstructed the lake level since the past $6.8 \mathrm{ka}$ by using paleolake shoreline records, and it showed that the paleolake level was at least $7 \mathrm{~m}$ higher than the present and gradually shrank till now. Chun et al. (2017) and Chun et al. (2018) has reported the variations of precipitation, temperature, and population in recent 50 years and further pointed out their effects on the changes of the lake level and vegetation coverage, and the results suggested that the variation of precipitation was the most fundamental factor for the recovery of vegetation and the rise of the lake level.

Element is one of the ideal proxies to detect the paleoclimate changes and can be superiorly and rapidly obtained by X-ray fluorescence (XRF) core scanning (Rothwell and Rack, 2006; Thomson et al., 2006; Liang et al., 2012). It has been widely applied in deep-sea sediments (Haug et al., 2001; Ziegler et al., 2008), lake sediments (Zhao et al., 2010; Li et al., 2016; Chen et al., 2021; Wu et al., 2012), and aeolian depositions (Liang et al., 2012; Liu et al., 2020). It has been proved to be well correlated with conventional XRF by contrast in lots of elements (Liang et al., 2012; Niu et al., 2019; Zhang X. et al., 2020). Different elements respond diversely to weathering, humidity, and temperature changes due to their own chemical and physical properties. The element ratio like $\mathrm{Sr} / \mathrm{Rb}, \mathrm{Sr} / \mathrm{Ca}, \mathrm{Mg} / \mathrm{Ca}, \mathrm{Si} / \mathrm{Fe}$, and $\mathrm{Fe} / \mathrm{Mn}$ can be used to reflect the climate variation (Liang et al., 2012;
Chen et al., 2021), and the single stable elements like Fe, Mn, Ti, $\mathrm{Rb}$, and $\mathrm{Zr}$ also can be used to indicate the climate changes (Haug et al., 2001; Li et al., 2016). However, the paleoclimatic indications of elements under different climatic conditions are complicated and need to be further clarified or combined with other proxy indexes.

In this study, we presented the elements, color results of an 11.7-m lacustrine sediment core CG18B from Chagan Nur in the southern Mongolian Plateau. The changes of the lake level and surface erosion in the catchment during the Holocene were reconstructed. Furthermore, we discussed the relationship between lake environmental changes and the variation of EASM precipitation based on the pollen record from the same lake. Finally, it was figured out how the lake environment responded to EASM precipitation variation during the Holocene in northern China.

\section{GEOGRAPHICAL SETTING}

Chagan Nur $\left(43^{\circ} 26^{\prime} 11.68^{\prime \prime} \mathrm{N}, 115^{\circ} 01^{\prime} 36.98^{\prime \prime}\right.$ E, $1,013 \mathrm{~m}$ a.s.l. Figure 1 and Figure 2), an inland-closed lake situates on the southeastern Mongolian plateau, northern China. It covers a total area of $\sim 108 \mathrm{~km}^{2}$ consisting of two lakes, east and west, in which the west lake dried up in $2001 \mathrm{AD}$, only leaving the east lake with an area of $22 \mathrm{~km}^{2}$. The elevation of the Chagan Nur basin is lower than 1,500 m, with the Otindag Sandy Land lying to the south and the Abaga Lava Platform to the north, basically appearing as the pattern of high in the south and low in the north. The Gogusty and Engeer rivers originating from the Otindag Sandy Land from the southern direction provide most of the fresh water to Chagan Nur Lake in the rainy season (June to September). 


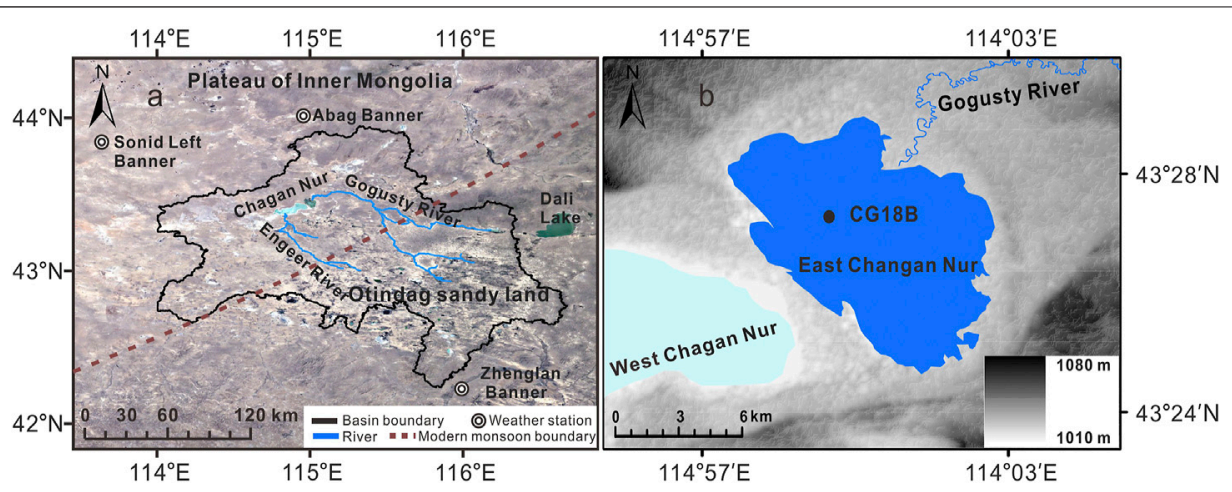

FIGURE 2 | Detailed information of Chagan Nur basin. (A) Li et al., (2020); (B) boundary of east Chagan Nur and the CG18B core.

The Chagan Nur basin is dominated by the typical semiarid temperate continental climate. The mean annual temperature is $\sim 3.5^{\circ} \mathrm{C}$. The annual precipitation in the basin is $\sim 270 \mathrm{~mm}$ (Chun et al., 2017; Li et al., 2020), and more than $70 \%$ of the rainfalls occur in the rainy season (June to September) which is transported by the EASM from the Pacific and the Indian Ocean. The modern vegetation landscape in the region is typical dry steppes consisting primarily of grasslands, sandy deserts, and few forests.

\section{MATERIALS AND METHODS}

\section{The X-ray Fluorescence Core Scanner}

The $11.7 \mathrm{~m}$ sediment core (CG18B) was retrieved in September 2018 from the center of east Chagan Nur Lake at the water depth of about $2.5 \mathrm{~m}$ by the UWITEC platform produced by Austria and then split it down from the middle in the lab. Before the scanning XRF measurement, the fresh sample surface was flattened and smoothed to eliminate scanning errors and then was quickly covered with preservative film to isolate the sample from the pollution of atmospheric dust. After the preparatory work, the elemental counts of the lake's core were measured by the XRF Core Scanner at the Key Laboratory of Western China's Environmental Systems (Ministry of Education) of Lanzhou University. The CG18B core was scanned in the conditions of $10 \mathrm{kV}-10 \mathrm{~mA}, 5 \mathrm{~mm}$, no filter, and $10 \mathrm{~s}$ scanning time to get the elements of $\mathrm{Al}, \mathrm{Si}, \mathrm{S}, \mathrm{K}, \mathrm{Ca}, \mathrm{Ti}$, and Fe and $30 \mathrm{kV}-20 \mathrm{~mA}, 5 \mathrm{~mm}$, Pd-Thick filter, and $20 \mathrm{~s}$ scanning time to get the elements of $\mathrm{Cu}$, $\mathrm{Zn}, \mathrm{Ga}, \mathrm{Br}, \mathrm{Rb}, \mathrm{Sr}$, and Pb (Richter et al., 2006; Weltje and Tjallingii, 2008). The validity of parameter setting was carried out by the inspection of instrument parameters. All elements were recorded by counts per second (cps).

A total of 27 bulk sediment samples were collected from CG18B core for accelerator mass spectrometry (AMS) radiocarbon dating. We compounded the graphite in the ${ }^{14} \mathrm{C}$ dating laboratory in Lanzhou University by the normative approach and dated by accelerator mass spectrometry (AMS) in Peking University. All ${ }^{14} \mathrm{C}$ ages were recalibrated to calendar years using the IntCal20 calibration curve (Reimer et al., 2020). The ages are expressed as years before present (BP) where

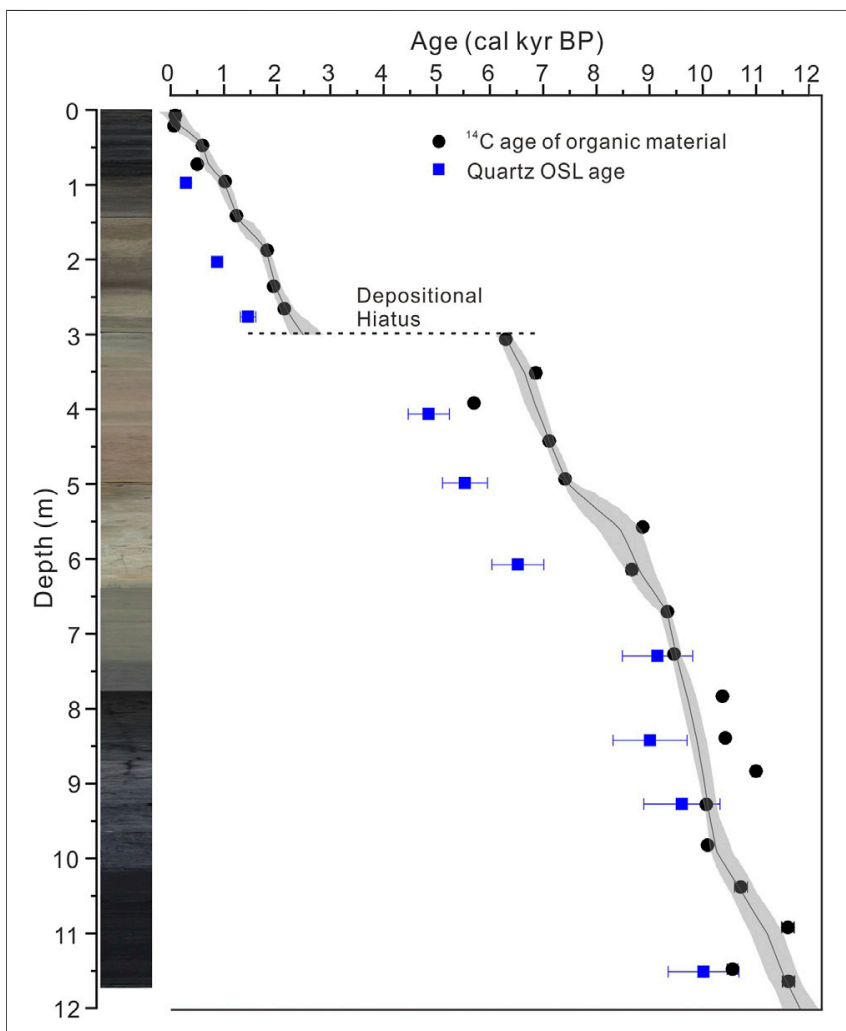

FIGURE 3 | Lithology, quartz OSL ages, ${ }^{14} \mathrm{C}$ ages of bulk organic materials, and age-depth model for sediment core CG18B from Chagan Nur (Redraw accorded by Li et al., 2020 with the IntCal20 curve).

"present" is defined as AD 1950. The top two samples (2 and $14 \mathrm{~cm}$ ) were 184 and $136 \mathrm{cal} \mathrm{yr} \mathrm{BP.} \mathrm{Therefore,} \mathrm{we} \mathrm{employed} \mathrm{the}$ 136 yrs as the reservoir age to correct all the ages. 10 luminescence dating samples are collected from the core CG18B for chronology determination in Lanzhou University. The measured luminescence dating ages from $728 \mathrm{~cm}, 926 \mathrm{~cm}$, and $1,150 \mathrm{~cm}$ of the core are consistent to ${ }^{14} \mathrm{C}$ age, while other luminescence dating ages have shown a systematic underestimation comparing to their ${ }^{14} \mathrm{C}$ ages primarily due to the exact water content is underestimated. As a result, the chronology of core CG18 is 


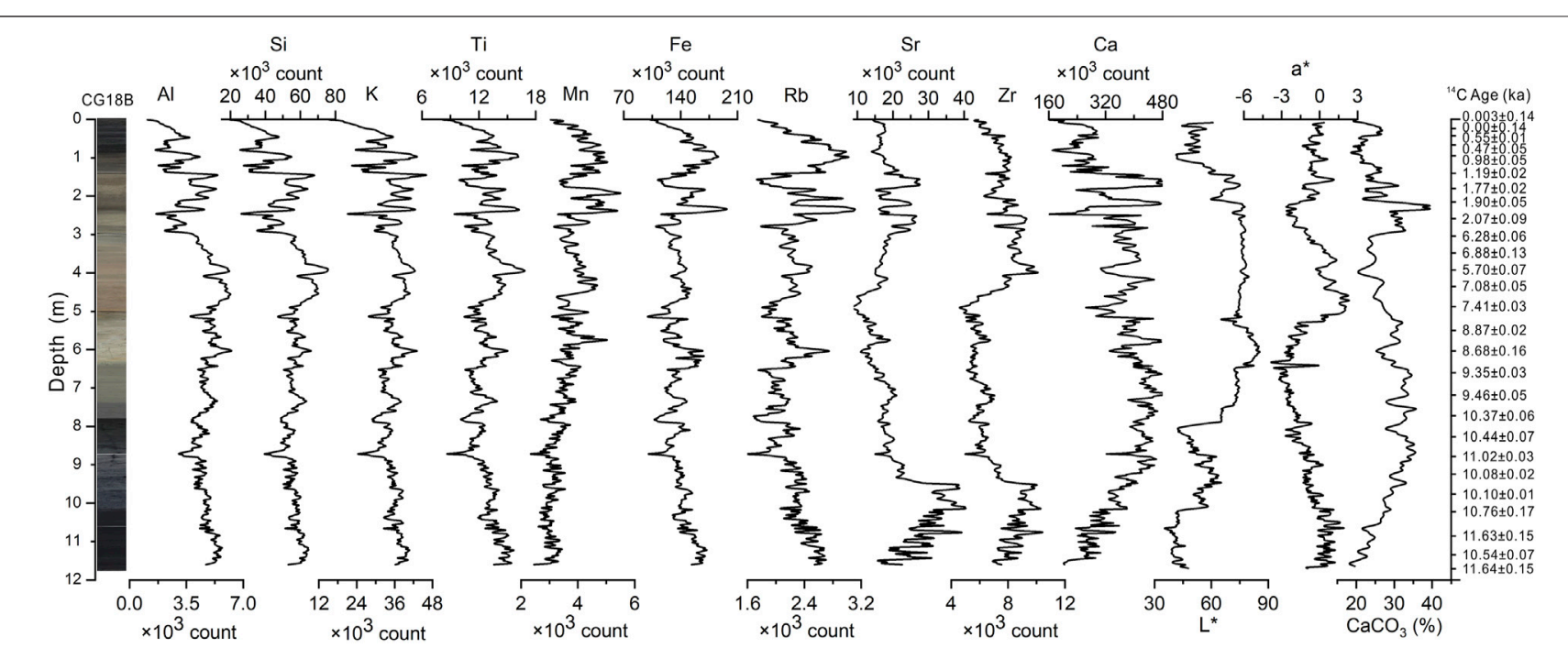

FIGURE 4 | Lithology, ${ }^{14} \mathrm{C}$ ages, elements, color, and carbonate indexes data of core CG18B.

established by using all ${ }^{14} \mathrm{C}$ ages with Bacon age-depth modeling (Blaauw and Christen, 2011) and the results are modified in Figure 3 according to Li et al., 2020.

\section{The Proxy Indexes of Color and Grain Size Measurement}

The color and grain size from core CG18B are measured and analyzed at the Key Laboratory of Western China's Environmental Systems at Lanzhou University. The chroma of the samples was measured by using the Avaatech AV60626 XRF Core Scanner when the fresh samples were split immediately to avoid the influence of oxidation.

A total of 469 samples from the core were used for grain size measurement. We treated the samples in the lab of Lanzhou University and followed the ways of Peng et al. (2005). For each sample, the $0.2-0.25 \mathrm{~g}$ dry sample was treated with $10 \% \mathrm{H}_{2} \mathrm{O}_{2}$ in the heating plate at $220^{\circ} \mathrm{C}$ to remove the organic material first, and then we added the $10 \mathrm{ml}$ of $10 \% \mathrm{HCl}$ to remove the carbonate content. The samples were soaked in distilled water to remove the acidic ions and stand for $10 \mathrm{~h}$. After siphoning off the upper liquids by a rubber hose, we added $10 \mathrm{ml}$ of $0.1 \mathrm{~mol} / \mathrm{L}$ $\left(\mathrm{NaPO}_{3}\right)_{6}$ with an ultrasonicator for $10 \mathrm{~min}$ to disperse the samples and then tested the dispersed samples using Malvern Master Sizer 2000.

\section{RESULTS}

\section{Lithology and Chronology}

All of these sediments from the core CG18B are consisted of lacustrine clay and silty clay. The details of the sedimentary structure are as follows: the uppermost $2.4 \mathrm{~m}$ of the core is black clay interbedded with sandy clay layers at depths of $0.9-1.1 \mathrm{~m}$ and $1.7-2 \mathrm{~m}$; the light brown to blue-gray clay is present at the depth of 2.4-6.4 m; at 6.4-11.7 m, there is black

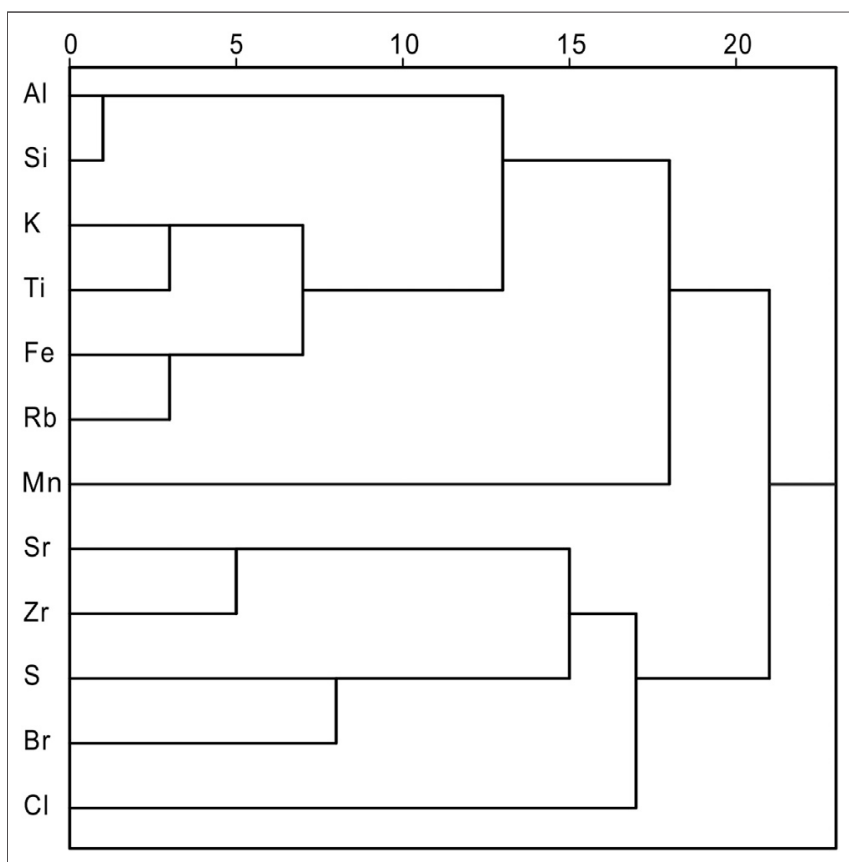

FIGURE 5 | Tree cluster analysis of elements, based on data correlation.

mud with no obvious structure but the color changes to light black in the upmost 7.4-6.4 $\mathrm{m}$ of the core; poorly sorted and poorly rounded gray sandy gravels occur at 11.7-11.8 $\mathrm{m}$ (Li et al., 2020).

Both the ${ }^{14} \mathrm{C}$ dating ages and luminescence dating ages show the lake sediments were deposited since the early Holocene (Figure 3, after $11.7 \mathrm{ka})$. An age jump occurred between the ${ }^{14} \mathrm{C}$ age of $2.086 \pm 0.067 \mathrm{cal} \mathrm{kyr} \mathrm{BP}$ at $264 \mathrm{~cm}$ and $6.274 \pm 0.050 \mathrm{cal} \mathrm{kyr} \mathrm{BP}$ at $305 \mathrm{~cm}$ in the core, indicating that the deposition hiatus occurred between the depths of 2.64-3.05 m. As a result, the age-depth 


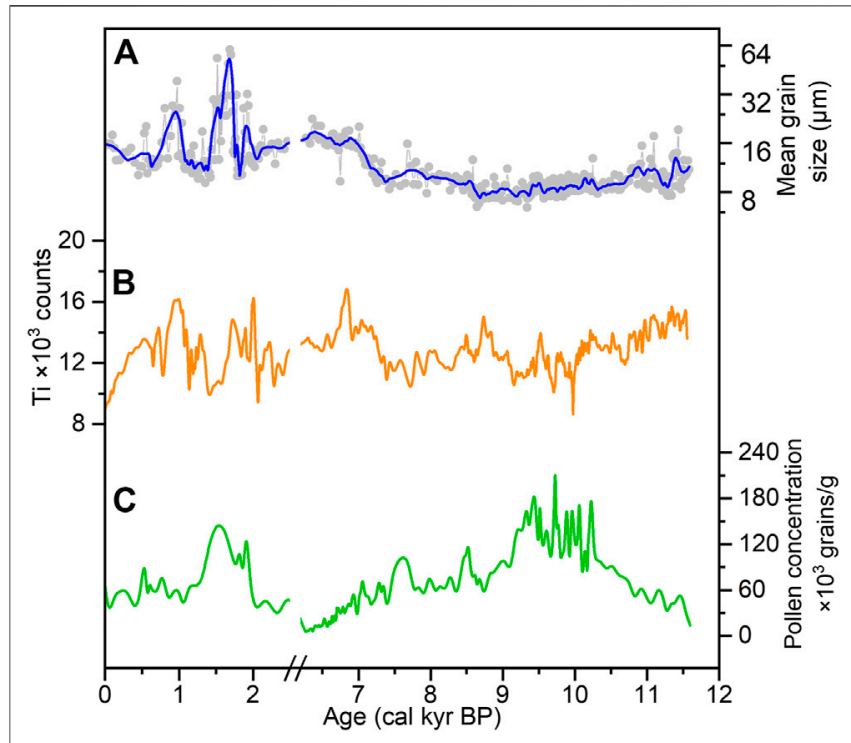

FIGURE 6| Mean grain size, (A) the Ti content, (B) pollen concentration, and (C) (Li et al., 2020) of Chagan Nur.

model was established separately for the depths of $0-3 \mathrm{~m}$ and 3-11.7 $\mathrm{m}$. The resulting age-depth model for core CG18B is illustrated in Figure 3.

\section{The Results of Chroma and Elements}

The measured elements of samples from the CG18B core are illustrated in Figure 4. The contents of $\mathrm{Al}, \mathrm{Si}, \mathrm{K}$, and Ti vary with the depth. The relatively stable and high contents of $\mathrm{Al}, \mathrm{Si}, \mathrm{K}$, and Ti occur at the depth of 11.7-5 $\mathrm{m}$ and then increase to the highest content in 5-3 m, whereas the contents of $\mathrm{Al}, \mathrm{Si}, \mathrm{K}$, and Ti drop obviously at the depth of 3-0 m. Fe and Rb contents show the identical trend of the gradual decrease in 11.7-6.5 $\mathrm{m}$ and then appear as a slight peak at the depth of $6.5-5.5 \mathrm{~m}$, and the contents keep stable and low in 5.5-3 m, followed by a distinct fluctuation at the depth of 3-0 m. The high values of $\mathrm{Sr}$ and $\mathrm{Zr}$ occur at the depth of 11.7-9.5 $\mathrm{m}$ and the contents slightly reduce at the depth of 9.5-5 m. The following variations of $\mathrm{Sr}$ and $\mathrm{Zr}$ at the depth of 5-0 $\mathrm{m}$ exhibit discrepancies, in which the highest $\mathrm{Zr}$ content occurs at the depth of 4-2.5 m, while the Sr content reaches the maximum at the depth of 3-1.5 m.

Correlation analysis of elements data indexes of core CG18B are further classified by tree cluster analysis (Figure 5). $\mathrm{Al}$ and $\mathrm{Si}$ (0.97), $\mathrm{K}$ and $\mathrm{Ti}(0.88)$, and $\mathrm{Fe}$ and $\mathrm{Rb}(0.86)$ are highly correlated $\left(R^{2}>0.8\right) ; \mathrm{Zr}$ and $\mathrm{Sr}(0.78)$ and $\mathrm{S}$ and $\mathrm{Br}(0.57)$ also have moderate correlations. Therefore, all the elements are divided into five branches by the tree cluster analysis initially, and then $\mathrm{Al}$, $\mathrm{Si}, \mathrm{K}, \mathrm{Ti}, \mathrm{Fe}$, and $\mathrm{Rb}$ are classified as the same class according to their variation tendency and correlation.

For chroma analysis (Figure 4), the indices of $\mathrm{a}^{*}$ are used to represent the degree of redness from green (negative value) to red (positive value), respectively. Chromas in Chagan Nur lake sediments showed different patterns. Two peaks of $a^{\star}$ can be recognized in 11.7-9 $\mathrm{m}$ and $6.5-3 \mathrm{~m}$ and two low ebbs are in $9-6.5 \mathrm{~m}$ and $3-0 \mathrm{~m}$.

\section{DISCUSSION}

\section{The Variation of Stable Element Ti Recorded Surface Erosion at Chagan Nur Basin}

$\mathrm{Al}, \mathrm{K}, \mathrm{Ti}, \mathrm{Fe}$, and $\mathrm{Rb}$ have the stable chemical property which is almost unaffected by surface chemical weathering and almost shows the same change (Figure 4), they are regarded as rockforming elements and are enriched in coarse particle and only transported to the lake by surface erosion in semiarid and arid lake basin (Shen et al., 2013b; Li et al., 2016; Zhang et al., 2017; Zhang et al., 2020; Tao. 2020; Chen et al., 2021). The result of mean grain size proxy also shows the similar change with these stable elements (see Figure 6, Ti and mean grain size). In 10.5-7.5 ka, Ti shows a relatively low content (about $12 \times$ $10^{3}$ count) correspondingly with the decrease in mean grain size which indicated the weak surface erosion during this period. In 11.7-10.5 $\mathrm{ka}$ and 7-6.2 $\mathrm{ka}$, the high content of $\mathrm{Ti}\left(15 \times 10^{3}\right.$ count) correspondingly with the increase in mean grain size suggested that the surface erosion became strong. Over the past 2,500 years, the value of $\mathrm{Ti}$ becoming much more unstable indicated that the surface erosion process became more complex in this period.

The results of pollen concentration from core CG18B also supported the surface erosion result indicated by $\mathrm{Ti}$. It has been reported that pollen concentration is one of the reliable proxies to reflect the vegetation coverage or humidity changes in the past period (Liu et al., 2002; Jiang et al., 2006; Zhao and $\mathrm{Yu}, 2012$; Shen, 2013a). The vegetation recovery improvement in the Loess Plateau that had been reported could efficiently stop the water loss and soil erosion (Wang et al., 2016). At the same time, loess profiles also have revealed the degraded climate can result in vegetation reduction and desertification (mean grain size increase) and even cause the lack of loess sediments by the strong wind erosion (Stevens et al., 2018; Hao et al., 2013), so that the vegetation coverage variation is the appropriate proxies to reflect the change of surface erosion.

As illustrated in Figure 6, the $\mathrm{Ti}$, mean grain size, and the pollen concentration show a similar trend. The low content of pollen concentration but the high value of mean grain size during $11.7-10.5 \mathrm{ka}$ and $7-6.2 \mathrm{ka}$ indicated the poor vegetation coverage, while the high pollen concentration and the low level of mean grain size during $10.5-7 \mathrm{ka}$ indicated the lush vegetation. Correspondingly, the high content of $\mathrm{Ti}$ in 11.7-10.5 ka and 7-6.2 ka indicated strong surface erosion but low in 10.5-7 ka suggested surface erosion became low. The same situation also has been reported in Huahai Lake (Li et al., 2016) and Hurleg Lake (Zhao et al., 2010), which revealed that stable elements were abundant when the grain size turned coarse.

In the past 2,500 years, the instabilities and complexities of the pollen concentration and grain size might be caused by human activities. Zhang et al. (2012) has reported that a number of human activities have been recorded in the Chagan Nur basin such as the agricultural activities causing the vegetation degradation during the past 2000 years. In addition, human activities could cause the unconformity between the sand 


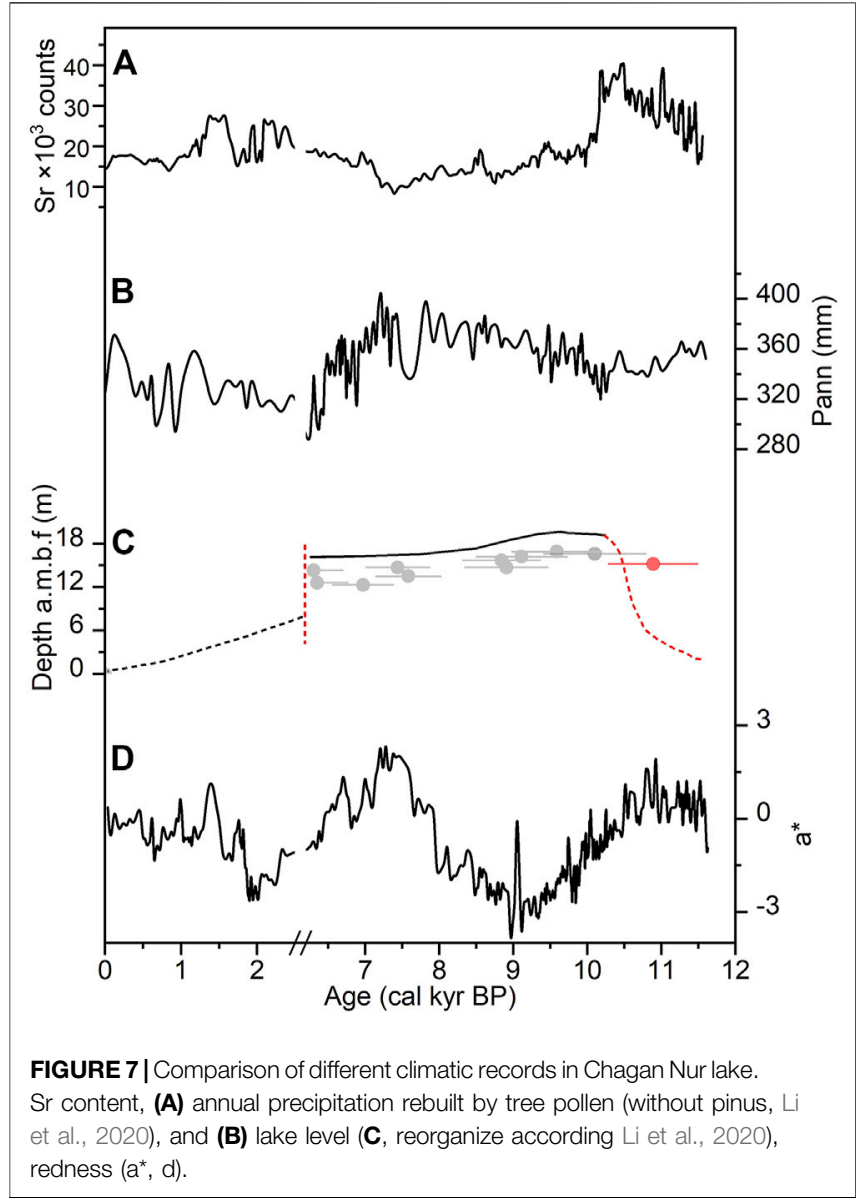

storm and EASM like the abnormal sand storm during the wet period in northern China (Chen et al., 2021).

\section{The Sr Element, Color ( $\left.a^{*}\right)$ in CG18B Core Revealed the Lake-Level Change of Chagan Nur Lake During the Holocene}

$\mathrm{Sr}$ is a kind of active element which can be leaching from land surface during the wet and warm period by strong chemical weathering in typical monsoon area and then enrich in lake sediments (Liu et al., 2020; Liang et al., 2012; Jin et al., 2006; Wu et al., 2012). However, Sr in arid Chagan Nur Lake shows the opposite result since $11.7 \mathrm{ka}$ (Figure 7) that high lake level correlated with low content of $\mathrm{Sr}$ or shallow lake level correlated with high content of Sr and it might be affected by lacking precipitation ( $\mathrm{Li}$ et al., 2020) or weak chemical weathering. Zhang et al. (1994) have presented that the variations of $\mathrm{Sr}$ element and salinity that generally exists in the linear positive correlation in the arid Qinghai Lake, which indicates that the saltier the lake water, the higher the content of $\mathrm{Sr}$, correspondingly, and $\mathrm{Sr} / \mathrm{Ca}$ extracted from Eucypris inflate also used to rebuild the lake level change of Qinghai Lake. Therefore, Sr content in arid Chagan Nur Lake may be influenced by lake-level variation since $11.7 \mathrm{ka}$. $\mathrm{a}^{*}$ (redness) also has some correspondence with $\mathrm{Sr}$, for the value of $\mathrm{a}^{*}$ varies synchronously with the content of ferric iron mineral (Ji et al., 2005) which could be influenced by oxidation environment caused by lake level in Chagan Nur Lake. As illustrated in Figure 7, the content of $\mathrm{Sr}$ exhibited high value during 11.7-10 ka in keeping with the small and shallow lake and less precipitation, leading to the lake water dissolving more oxygen and keeping the lake in strong oxidized condition, so that the low lake level not only provided enough oxygen content to the lake water but also promoted the enrichment of $\mathrm{Sr}$ in the lake water. In 10-6.2 ka, the Sr content decreased or attenuated in line with the rising of precipitation and the lake level, correspondingly, $\mathrm{a}^{*}$ kept the lowest value in $10.5-8 \mathrm{ka}$, which meant the high lake level could reduce the oxygen in lake water and attenuate the concentration of $\mathrm{Sr}$ in lake water. The high $\mathrm{a}^{*}$ value appeared in 8-6.2 ka might have been caused by the hiatus that happened during 2.5-6.2 ka, which caused the lake sediments formed in 8-6.2 ka to be exposed to the air and kept a highly oxidized state in the dried-up lake environment. The high values of Sr during 2-0 ka were corresponding with the shrunken lake level, high $\mathrm{a}^{*}$ value, and poor precipitation during the late Holocene which was the same situation with 11.7-10 ka that the small-shallow lake level and precipitation enhanced the oxidized condition and enriched the content of $\mathrm{Sr}$ in lake water (Figure 7).

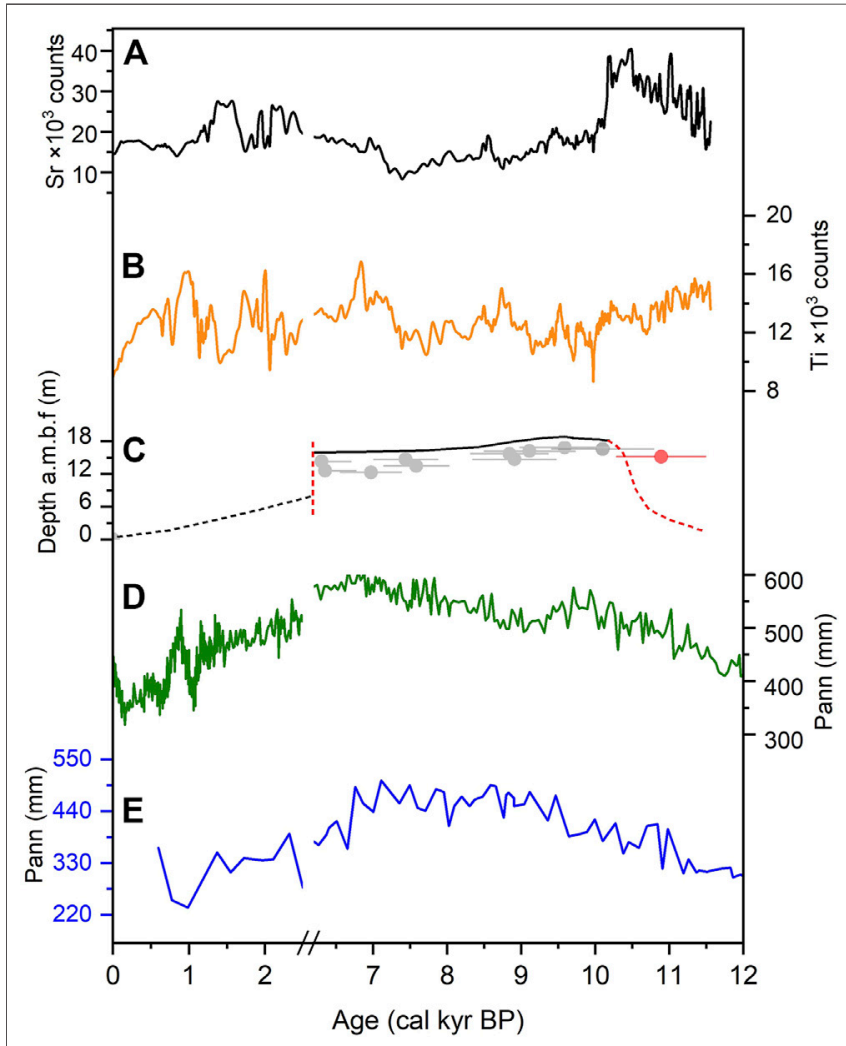

FIGURE 8 | Regional comparison by Sr content, (A) Ti content, and (B) lake level (C, reorganize according Li et al., 2020) with precipitation from Gonghai (D, Chen et al., 2015) and Bayan Chagan Nur (E, Jiang et al., 2006). 


\section{The Element Indicated Surface Erosion and Lake-Level Changes and Compared With Precipitation Recorded by Pollen and Lake Level Changes Rebuilt by Paleolake Shorelines}

The lake environmental changes since $11.7 \mathrm{ka}$ in Chagan Nur were reconstructed by proxy indexes of elements and color. The results suggested that the shallow lake with relatively strong surface erosion occurred during 11.7-10.5 ka. The weakening surface erosion, high lake level, and fresh lake water environment occurred during 10.5-7 ka. The strong surface erosion, relatively low lake level, and salinity lake water occurred in 7-6.2 ka and 2-0 ka of Chagan Nur Lake. The influence of human activities on the lake environmental changes has increased significantly during the past $2 \mathrm{ka}$.

As illustrated in Figure 7, the precipitation changes have been reconstructed by the pollen record from the Chagan Nur Lake. The results suggested that the variation of EASM dominated the paleoenvironmental changes in Chagan Nur basin at the margin of EASM dominance, which not only influenced the lake level but also influenced the vegetation coverage and surface erosion. The variations of precipitation reconstructed by pollen records from Chagan Nur (Li et al., 2020), Bayanchagan (Jiang et al., 2006), and Gonghai (Chen et al., 2015) are basically consistent (Figure 8) and show a spatial trend of decreasing from the south to north, which indicated that the strength of EASM is gradually reduced from southern China to northern China. During 11.7-10 ka, reconstructed precipitation by pollen showed a relatively low value, and the values of Sr and Ti kept at high level, indicating the EASM was weak and coarse grains were transported to the lake in this period. Pollen records from the Chagan Nur lake showed the herbaceous plant predominated in this region (Li et al., 2020), and the vegetation landscape was typical dry steppe. The less precipitation reduces runoff into the lake, and the poor vegetation coverage enhances surface erosion, both of which cause an increase in $\mathrm{Ti}$ and $\mathrm{Sr}$ contents in the lake. In 10-7 ka, the precipitation increased steadily and hit the peak in 8.5-7 ka, and the low values of $\mathrm{Sr}$ and Ti indicated that the EASM became strong, as a result of the rising lake level, the improved vegetation coverage, the fine mean grain size, and the higher ratio of tree pollen in the neighborhood area (Jiang et al., 2006; Wen et al., 2017; Han et al., 2020; Li et al., 2020). During 7-6.2 ka and 2.5-0 ka, the precipitation decreased rapidly and the content of $\mathrm{Sr}$ and $\mathrm{Ti}$ shot up which indicated the weakening of EASM, the degradation of vegetation, and the intensifying of surface erosion. Furthermore, the drought event happened in Chagan Nur during 6.2-2.5 ka which caused the depositional hiatus. When the lake reappeared in $2.5 \mathrm{ka}$, it might have been small and shallow as a result of the low lake water as indicated by the Sr value, shoreline record (Liu et al., 2017; Li et al., 2020), and strong surface erosion indicated by $\mathrm{Ti}$ value, which suggested the weakened EASM causing the diminishing precipitation during this period. Actually, the
EASM intensity of the monsoonal region in northern China was weakest during the late Holocene because the northern Hemisphere summer insolation was minimum during the Holocene (Laskar et al., 2004).

\section{CONCLUSION}

Based on the chronology obtained by the radiocarbon and luminescence dating, in combination with the results of elements, color from an $11.7 \mathrm{~m}$ Chagan Nur lacustrine core, we have reconstructed variations of the surface erosion and lake level on the fringe of modern EASM dominance in northern China during the Holocene. The results show that the lake environment during the Holocene can be identified into four stages. The strong surface erosion and low lake water environment occurred at 11.7-10.5 ka. During 10.5-7 ka, the weakened surface erosion, rising lake level, and a better land coverage environment occurred at Chagan Nur lake basin. After that, the surface erosion gradually strengthened during 7-6 ka and from $2.5 \mathrm{ka}$ to present, and lake level declined obviously during the Holocene period.

The variation in lake basin surface erosion, lake level, and land coverage of Chagan Nur have correlated with the EASM precipitation changes during the Holocene, indicating that the variation of EASM during the Holocene directly dominated the changes of surface erosion and lake level in arid northern China. During the past $2 \mathrm{ka}$, human activity has played a key role in the environmental changes at Chagan Nur Lake Basin.

\section{DATA AVAILABILITY STATEMENT}

The original contributions presented in the study are included in the article/Supplementary Material, and further inquiries can be directed to the corresponding author.

\section{AUTHOR CONTRIBUTIONS}

GL contributed to the conception and design of the study. ZW organized the database. $\mathrm{ZW}$ performed the statistical analysis. $\mathrm{ZW}$ wrote the first draft of the manuscript. ZW, XW, SG, YD, YZ, and ST did experiments. GL, ZW, WZ, and MJ discussed the data. All authors contributed to manuscript revision, reading, and approved the submitted version.

\section{FUNDING}

This work was supported by the National Natural Science Foundation of China (No. 41790423) and the Fundamental Research Funds for the Central Universities (No. lzujbky2021-ey22). 


\section{REFERENCES}

An, Z., Colman, S. M., Zhou, W., Li, X., Brown, E. T., Jull, A. J. T., et al. (2012). Interplay between the Westerlies and Asian Monsoon Recorded in Lake Qinghai Sediments since 32 Ka. Scientific Rep. 2, 619. doi:10.1038/srep00619

An, Z. S., Wu, G. S., Li, J. P., Sun, Y. B., Liu, Y. M., Zhou, W. J., et al. (2015). Global Monsoon Dynamics and Climate Change. Sci. Rep. 43, 29-77. doi:10.1038/ srep00619

Blaauw, M., and Christen, J. A. (2011). Flexible Paleoclimate Age-Depth Models Using an Autoregressive Gamma Process. Bayesian Anal. 6, 457-474. doi:10.1214/ba/1339616472

Chen, C., Tao, S., Zhao, W., Jin, M., Wang, Z., Li, H., et al. (2021). Holocene lake Level, Vegetation, and Climate at the East Asian Summer Monsoon Margin: A Record from the Lake Wulanhushao basin, Southern Inner Mongolia. Palaeogeogr. Palaeoclimatol. Palaeoecol. 561, 110051. doi:10.1016/ j.palaeo.2020.110051

Chen, F. H., Chen, S. Q., Zhang, X., Chen, J. H., Wang, X., Gowan, E. J., et al. (2020). Asian Dust-Storm Activity Dominated by Chinese Dynasty Changes since 2000 BP. Nat. Commun. 11, 992. doi:10.1038/s41467-020-14765-4

Chen, F. H., Xu, Q. H., Chen, J. H., Birks, H. J., Liu, J. B., Zhang, S. R., et al. (2015). East Asian Summer Monsoon Precipitation Variability since the Last Deglaciation. Sci. Rep. 5, 11186. doi:10.1038/srep11186

Chun, X., Su, R. G., Liu, J. Y., Liang, W. J., Yong, M., and Ulambadrakh, K. (2017). Climatic Implications on Variations of Qehan Lake in the Arid Regions of Inner Mongolia during the Recent Five Decades. Environ. Monit. Assess. 189, 14. doi:10.1007/s10661-016-5721-5

Chun, X., Yong, M., Liu, J. Y., and Liang, W. J. (2018). Monitoring Land Cover Change and its Dynamic Mechanism on the Qehan lake basin, Inner Mongolia, north China, during 1977-2013. Environ. Monit. Assess. 190, 205. doi:10.1007/ s10661-018-6582-X

Goldsmith, Y., Broecker, W. S., Xu, H., Polissar, P. J., Demenocal, P. B., Porat, N., et al. (2017). Northward Extent of East Asian Monsoon Covaries with Intensity on Orbital and Millennial Timescales. Proc. Natl. Acad. Sci. USA. 114, 1817-1821. doi:10.1073/pnas.1616708114

Han, P., and Liu, X. Q. (2017). The Climate Evolution Inferred from Chagan Nuur in Middle East Part of Inner Mongolia since the Last 7000years. Quat. Sci. 37, 1382-1390. (In Chinese with English abstract). doi:10.11928/j.issn.10017410.2017.06.20

Han, Y., Liu, H. Y., Zhou, L. Y., Hao, Q., and Cheng, Y. (2020). Postglacial Evolution of forest and Grassland in southeastern Gobi (Northern china) Sciencedirect. Quat. Sci Rev 248, 106611. doi:10.1016/j.quascirev.2020.106611

Hao, Q. Z., Wang, L., Oldfield, F., Peng, S. Z., Qin, L., Song, Y., et al. (2013). Delayed Build-Up of Arctic Ice Sheets during 400,000-year Minima in Insolation Variability. Nature 490, 393-396.

Haug, G. H., Hughen, K., Sigman, D., Peterson, L. C., and Röhl, U. (2001). Southward Migration of the Intertropical Convergence Zone through the Holocene. Science 293, 1304-1308. doi:10.1126/science.1059725

Ji, J., Ji, S., Balsam, W., Chen, J., Liu, L., and Liu, X. (2005). Asian Monsoon Oscillations in the Northeastern Qinghai-Tibet Plateau Since the Late Glacial as Interpreted From Visible Reflectance of Qinghai Lake Sediments. Earth Planet. Sci. Lett. 233, 61-70.

Jian, N., Wang, Y., Dong, J., Yang, J. S., Tian, F., Liu, J., et al. (2016). Sedimentary Record of Environmental Evolution since Ca 2000 Cal Yr B P Ago in Qehan Lake, Inner Mongolia. Geol. Bull. China 35, 953-962. (In Chinese with English abstract).

Jiang, W., Guo, Z., Sun, X., Wu, H., Chu, G., Yuan, B., et al. (2006). Reconstruction of Climate and Vegetation Changes of Lake Bayanchagan (Inner Mongolia): Holocene Variability of the East Asian Monsoon. Quat. Res. 65, 411-420. doi:10.1016/j.yqres.2005.10.007

Jin, Z., Cao, J., Wu, J., and Wang, S. (2006). A Rb/Sr Record of Catchment Weathering Response to Holocene Climate Change in Inner Mongolia. Earth Surf. Process. Landforms 31, 285-291. doi:10.1002/esp.1243

Laskar, J., Robutel, P., Joutel, F., Gastineau, M., Correia, A. C. M., and Levrard, B. (2004). A Long-Term Numerical Solution for the Insolation Quantities of the Earth. AઐA 428, 261-285. doi:10.1051/0004-6361:20041335

Li, G., Wang, Z., Zhao, W., Jin, M., Wang, X., Tao, S., et al. (2020). Quantitative Precipitation Reconstructions from Chagan Nur Revealed Lag Response of East
Asian Summer Monsoon Precipitation to Summer Insolation during the Holocene in Arid Northern China. Quat. Sci. Rev. 239, 106365. doi:10.1016/ j.quascirev.2020.106365

Li, Z., Wang, N. a., Cheng, H., and Li, Y. (2016). Early-middle Holocene Hydroclimate Changes in the Asian Monsoon Margin of Northwest China Inferred from Huahai Terminal lake Records. J. Paleolimnol 55, 289-302. doi:10.1007/s10933-016-9880-8

Liang, L., Sun, Y., Yao, Z., Liu, Y., and Wu, F. (2012). Evaluation of HighResolution Elemental Analyses of Chinese Loess Deposits Measured by X-ray Fluorescence Core Scanner. Catena 92, 75-82. doi:10.1016/ j.catena.2011.11.010

Liu, H., Xu, L., and Cui, H. (2002). Holocene History of Desertification along the woodland-steppe Border in Northern china. Quat. Res. 57, 259-270. doi:10.1006/qres.2001.2310

Liu, M. P., and Ha, S. (2015). Mid Holocene Paleolake Fluctuation of the Qehan Lake, Inner Mongolia, China. J. Desert Res. 35, 306-312. (In Chinese with English abstract).

Liu, X., Sun, Y., Vandenberghe, J., Cheng, P., Zhang, X., Gowan, E. J., et al. (2020). Centennial- to Millennial-Scale Monsoon Changes since the Last Deglaciation Linked to Solar Activities and North Atlantic Cooling. Clim. Past 16, 315-324. doi:10.5194/cp-16-315-2020

Niu, J., Zhang, W. X., Zhang, H. C., Duan, L. C., Wu, M. J., and Wang, L. M. (2019). The Characteristics of Geochemical Elements in Fuxian Lake Sediments and its Environmental Significance Based on XRF Core Scanning. Spectrosc. spectral Anal. 39, 2223-2227. (In Chinese with English abstract).

Peng, Y., Xiao, J., Nakamura, T., Liu, B., and Inouchi, Y. (2005). Holocene East Asian Monsoonal Precipitation Pattern Revealed by Grain-Size Distribution of Core Sediments of Daihai Lake in Inner Mongolia of north-central China. Earth Planet. Sci. Lett. 233, 467-479. doi:10.1016/j.epsl.2005.02.022

Reimer, P., Austin, W., Bard, E., Bayliss, A., Blackwell, P., Bronk Ramsey, C., et al. (2020). The IntCal20 Northern Hemisphere Radiocarbon Age Calibration Curve (0-55 Cal kBP). Radiocarbon 62, 725. doi:10.1017/rdc.2020.41

Richter, T. O., van der Gaast, S., Koster, B., Vaars, A., Gieles, R., de Stigter, H. C., et al. (2006). The Avaatech XRF Core Scanner: Technical Description and Applications to NE Atlantic Sediments. Geol. Soc. Lond. Spec. Publications 267, 39-50. doi:10.1144/gsl.sp.2006.267.01.03

Rothwell, R. G., and Rack, F. R. (2006). New Techniques in Sediment Core Analysis: an Introduction. Geol. Soc. Lond. Spec. Publications 267, 1-29. doi:10.1144/gsl.sp.2006.267.01.01

Shen, J. (2013a). Spatiotemporal Variations of Chinese Lakes and Their Driving Mechanisms since the Last Glacial Maximum: a Review and Synthesis of Lacustrine Sediment Archives. Chin. Sci. Bull. 58, 17-31. doi:10.1007/ s11434-012-5510-7

Shen, J., Wu, X., Zhang, Z., Gong, W., He, T., Xu, X., et al. (2013b). Ti Content in Huguangyan Maar lake Sediment as a Proxy for Monsoon-Induced Vegetation Density in the Holocene. Geophys. Res. Lett. 40, 5757-5763.

Stevens, T., Buylaert, J. P., Thiel, C., újvári, G., Yi, S., Murray, A. S., et al. (2018). Icevolume-forced Erosion of the Chinese Loess Plateau Global Quaternary Stratotype Site. Nat. Commun. 9, 983. doi:10.1002/grl.50740

Tao, S. X. (2020). Holocene lake Environmental Changes in the East Asian Summer Monsoon Limit Revealed by lake Geomorphy and Lacustrine Sediment Core Record from the Wulanhushao lake basin. Lanzhou, China: Lanzhou University.

Thomson, J., Croudace, I. W., and Rothwell, R. G. (2006). A Geochemical Application of the ITRAX Scanner to a Sediment Core Containing Eastern Mediterranean Sapropel Units. Geol. Soc. Lond. Spec. Publications 267, 65-77. doi:10.1144/gsl.sp.2006.267.01.05

Wang, S., Fu, B., Piao, S., Lü, Y., Ciais, P., Feng, X., et al. (2016). Reduced Sediment Transport in the Yellow River Due to Anthropogenic Changes. Nat. Geosci. 9, 38-41. doi:10.1038/ngeo2602

Weltje, G. J., and Tjallingii, R. (2008). Calibration of XRF Core Scanners for Quantitative Geochemical Logging of Sediment Cores: Theory and Application. Earth Planet. Sci. Lett. 274, 423-438. doi:10.1016/j.epsl.2008.07.054

Wen, R., Xiao, J., Fan, J., Zhang, S., and Yamagata, H. (2017). Pollen Evidence for a Mid-holocene East Asian Summer Monsoon Maximum in Northern China. Quat. Sci. Rev. 176, 29-35. doi:10.1016/j.quascirev.2017.10.008

Wu, X., Zhang, Z., Xu, X., and Ji, S. (2012). Asian Summer Monsoonal Variations During the Holocene Revealed by Huguangyan Maar Lake Sediment Record. Palaeogeo. Palaeoclimato. Palaeoeco. 323-325, 13-21. 
Zhang, E., Zhao, C., Xue, B., Liu, Z., Yu, Z., Chen, R., et al. (2017). Millennial-scale Hydroclimate Variations in Southwest China Linked to Tropical Indian Ocean since the Last Glacial Maximum. Geology 45, 435-438. doi:10.1130/g38309.1

Zhang, J., Tsukamoto, S., Jia, Y., and Frechen, M. (2016). Lake Level Reconstruction of Huangqihai Lake in Northern China since MIS 3 Based on Pulsed Optically Stimulated Luminescence Dating. J. Quat. Sci. 31, 225-238. doi:10.1002/ jqs. 2861

Zhang, P. X., Zhang, B. Z., Qian, G. M., Li, H. J., and Xu, L. M. (1994). The Study of Paleoclimatic Parameter of Qinghai Lake since Holocene. Quat. Sci. 03, 225-238. (In Chinese with English abstract).

Zhang, X. N., Zhou, A. F., Huang, Z. D., An, C. B., Zhao, Y. T., Yin, L. Y., et al. (2020b). Moisture Evolution in North Xinjiang (Northwest China) during the Last 8000 Years Linked to the Westerlies' winter Half-Year Precipitation. Quat. Res. 100. doi:10.1017/qua.2020.94

Zhang, X., Zhang, H., Chang, F., Ashraf, U., Peng, W., Wu, H., et al. (2020a). Application of Corrected Methods for High-Resolution Xrf Core Scanning Elements in lake Sediments. Appl. Sci. 10, 8012. doi:10.3390/app10228012

Zhang, X., Zhou, Y., Pang, J., Lu, H., Huang, C., Zhou, L., et al. (2012). The Relationship Between Environmental Changes and Human Activities during the medieval Warm Period and the Little Ice Age in Otindag Sandland by osl Dating. Quater. Sci. 32, 535-546. doi:10.3969/j.issn.1001-7410.2012.03.20

Zhao, C., Yu, Z., Zhao, Y., Ito, E., Kodama, K. P., and Chen, F. (2010). Holocene Millennial-Scale Climate Variations Documented by Multiple lake-level Proxies in Sediment Cores from Hurleg Lake, Northwest China. J. Paleolimnol 44, 995-1008. doi:10.1007/s10933-010-9469-6
Zhao, Y., and Yu, Z. (2012). Vegetation Response to Holocene Climate Change in East Asian Monsoon-Margin Region. Earth-Science Rev. 113, 1-10. doi:10.1016/j.earscirev.2012.03.001

Ziegler, M., Jilbert, T., de Lange, G. J., Lourens, L. J., and Reichart, G.-J. (2008) Bromine Counts from XRF Scanning as an Estimate of the marine Organic Carbon Content of Sediment Cores. Geochem. Geophys. Geosyst. 9, a-n. doi:10.1029/2007gc001932

Conflict of Interest: The authors declare that the research was conducted in the absence of any commercial or financial relationships that could be construed as a potential conflict of interest.

Publisher's Note: All claims expressed in this article are solely those of the authors and do not necessarily represent those of their affiliated organizations, or those of the publisher, the editors and the reviewers. Any product that may be evaluated in this article, or claim that may be made by its manufacturer, is not guaranteed or endorsed by the publisher.

Copyright (c) 2021 Wang, Li, Wang, Gou, Deng, Tao, Zhang, Yang, Zhao and Jin. This is an open-access article distributed under the terms of the Creative Commons Attribution License (CC BY). The use, distribution or reproduction in other forums is permitted, provided the original author(s) and the copyright owner(s) are credited and that the original publication in this journal is cited, in accordance with accepted academic practice. No use, distribution or reproduction is permitted which does not comply with these terms. 